\title{
The Complications of Cesarean Section at Teaching Hospital Gabriel TOURE, Bamako Mali
}

\author{
Abdoulaye Sissoko ${ }^{*}$, Alassane Traore ${ }^{2}$, Ibrahim Kante ${ }^{3}$, Amadou Bocoum ${ }^{1}$, \\ Soumana Oumar Traore4, Seydou Fane1, Daniel Dembele1, Aminata Kouma5, \\ Mamadou Sima ${ }^{3}$, Fatoumata K. Tounkara6, Amadou Fomba1, Ibrahima Teguete1, \\ Youssouf Traore', Soumaila Keita ${ }^{3}$, Niani Moukoro ${ }^{1}$ \\ ${ }^{1}$ Teaching Hospital Gabriel TOURE, Bamako, Mali \\ ${ }^{2}$ Teaching Hospital, Bamako, Mali \\ ${ }^{3}$ Teaching Hospital Point G, Bamako, Mali \\ ${ }^{4}$ District Hospital Commune V, Bamako, Mali \\ ${ }^{5}$ Teaching Hospital Kati, Bamako, Mali \\ ${ }^{6}$ Research Center CHU of Quebec, University of Laval, Quebec, Canada \\ Email: *asissoko65@yahoo.fr, abocoum2000@yahoo.fr, seydoufane@yahoo.fr, amadoufomba@yahoo.fr, \\ dembele.daniel87@gmail.com, tegueteibra@hotmail.com, aichaniani@yahoo.fr, dryoussouf.traore@gmail.com, \\ fatoumata-korika.tounkara.1@ulaval.ca, fatoumatakorika.tounkara@fmed.ulaval.ca, koumamit@yahoo.fr, \\ alassanetraore200@yahoo.fr, traoreoumar69@yahoo.fr, Ibrahimkante197462@gmail.com,drmsima@gmail.com, \\ keita_soumi@yahoo.fr
}

How to cite this paper: Sissoko, A., Traore, A., Kante, I., Bocoum, A., Traore, S.O., Fane, S., Dembele, D., Kouma, A., Sima, M., Tounkara, F.K., Fomba, A., Teguete, I., Traore, Y., Keita, S. and Moukoro, N. (2020) The Complications of Cesarean Section at Teaching Hospital Gabriel TOURE, Bamako Mali. Open Journal of Obstetrics and Gynecology, 10, 546-557.

https://doi.org/10.4236/ojog.2020.1040049

Received: March 21, 2020

Accepted: April 20, 2020

Published: April 23, 2020

Copyright $\odot 2020$ by author(s) and Scientific Research Publishing Inc. This work is licensed under the Creative Commons Attribution International License (CC BY 4.0).

http://creativecommons.org/licenses/by/4.0/ (c) (i) Open Access

\begin{abstract}
Cesarean operation permits to save the mother and fetus. However, in developing countries as ours, complications related to this cesarean are not to be neglected. It constitutes an important cause of maternal and fetal morbidity and mortality. Here we rapport the experience of our structure about the complications of cesarean. Objectives: The objectives of this study were to study the complications the complications of cesarean section at teaching hospital Gabriel TOURE, Bamako Mali. Materials and methods: We have carried out a cross sectional analytic study from January $1^{\text {st }} 2003$ to December $31^{\text {st }} 2013$. All the patients who gave birth by cesarean operation in gynecology-obstetric service of teaching hospital Gabriel TOURE were included during this period of study. Descriptive statistics were used, Chi-square test Pearson, and Cochran Armitage test have been used to calculate the P-value of trend. We performed multivariate analyses with a high alpha threshold of $10 \%$, and then logistic regression multivariate. Results: We have registered 28,376 deliveries with 9509 cases of cesarean (33.5\%) and a complication cesarean rate of $32 \%$ (3049/9509). The main risk factors for cesarean operation completions were adolescence primiparity, obesity, the non-realization of antenatal care, evacuations and co-morbidities. Intraoperative complications were dominated by he-
\end{abstract}


morrhage $8.3 \%$ and bladder lesion $1.1 \%$, whereas anemia (58.8\%) and parietal infection $(21.1 \%)$ dominated the postoperative complications table. The evacuation (Odds Ratio adjusted $(\mathrm{ORa})=1.96)$ as well pre-eclampsia/eclampsia $(\mathrm{ORa}=2.34)$ and the sicle cell disease $(\mathrm{ORa}=9.99)$ were the main influencing factors of material death. Praevia placenta $(\mathrm{ORa}=1.75)$ abruption placenta $(\mathrm{ORa}=11.08)$ and fetal malformation $(\mathrm{ORa}=2.21)$ dominated the influencing factors of perinatal death. Conclusion: The cesarean complications rates were high in our improvement of the quality of antenatal care. The reorganization and revitalization of the reference and against reference system will permit to program some cesarean operation to reduce the morbidity related to caesarean.

\section{Keywords}

Cesarean, Complication, Risk Factors, Morbidity, Mortality

\section{Introduction}

Cesarean section rates are increasing worldwide; the highest rates are in China 46.2\%, South America 41\% and Vietnam 35.6\% [1], in Western Europe 24.5\% and North America 32\% [1] [2]. In several African countries an increase in cesarean section rates is between $6.8 \%$ and $38.8 \%$ according to hospital studies [3] [4]. It has been reported that $68.5 \%$ of the 54 countries that had a cesarean rate below $10 \%$ were African [5]

Cesarean permits to treat difficulties related to vaginal delivery and risk situations of fetal asphyxia [6]; however its realization needs a well justified medical direction [7], which will effectively permit to avoid maternal and perinatal morbidity and mortality [8]. Cesarean operation increases maternal and fetal morbidity from 5 to 7 times compared with vaginal delivery [9] [10]. It's not harmless, and may cause major complication and sometimes permanent, disability or death, especially in structures where there are insufficient infrastructures and able to guarantee an adequate care [11]. The risk of complications is increased, especially in developing countries [12] [13].

The current situation complications of cesarean delivery rates in developing countries are very complex with large differences between countries, within countries, and between health centers. Complication rates of $14.5 \%$ to $33.5 \%$ have been reported by Van et al. [14], Norway 21.4\% [15] and United States 5.7\% [16]. According to African literature $16.95 \%$ is in Yaoundé (Cameroun), Ouagadougou (Burkina Faso) 18.8\% and 11.6\% Democratic Republic of Congo.

In Bamako Mali the rates of complications related to cesarean are variable: $22.7 \%, 31.3 \%$, and 33.3\% respectively with Mariko SL in 2008 [14]; Siby O in 2009 [17] and Kone AD in 2005 [18]. We have initiated this work to study the complications of maternal fetal cesarean in obstetric gynecology service of CHU-GT, determine the frequency of caesarean complication, identify the risk factors for 
complicated cesarean and establish the maternal fetal prognostic of complicated cesarean operation.

\section{Materials and Methods}

Our study was carried out in teaching hospital Gabriel TOURE (CHU-GT) of Bamako, Mali. It dealt with the third level of health pyramid of the country. It's a referral hospital. This may have an influence on the children and mothers prognosis [17] [18]. It's about a cross sectional analytic study on hospital data bases from January $1^{\text {st }} 2003$ to December $31^{\text {st }} 2013$, equal to a consecutive period of 11 years. Selection of samples has been comprehensive.

All the patients who gave birth through cesarean in obstetric gynecology service of teaching hospital Gabriel TOURE were included during the period of study.

This database contains more than 700 variables related to patients' demographic, medical and obstetric factors as well as pregnancy outcomes. A complete obstetric database of all obstetric admissions focusing on characteristics of delivered women, mode of delivery, cesarean indications, and maternal, fetal and immediate neonatal outcome was built to include all cesarean delivery recorded at teaching hospital Gabriel TOURE during the period of study. Data were collected from these complete obstetric files, as well as hospital birth registries, registries of on-call midwives, surgical reports, admissions records for the intensive care service.

The main variables of interest are related to socio-demographic characteristics (mother's age, marital status, level of education); behaviour characteristics (antenatal care); previous medical and obstetrical (previous cesarean, hypertension, diabetes, parity, gestity); pregnancy outcomes (maternal and perinatal death, Route of delivery, cesarean indications, prognosis maternal and fetal). It has been designed on the software SPSS version 20.0 and analyzed o software SAS (SAS Institute TNC, 9.4, Cary, North caroling a 27513).

Descriptive statics were used, Pearson's chi-square test, the cochram-armitage test has been used to calculate the $\mathrm{p}$-value of trend $\mathrm{P}<0.05$ was considered statistically significant. We performed multivariate analyses with a high alpha threshold of $10 \%$, then logistic regression multivariate. Logistic regression has been applied to appreciate the effect of maternal characteristics, obstetric practice, systemic factors on caesarean delivery rate and the complication. The database used for this analysis was reviewed and approved by the ethics committee of the Faculty of Medicine, Pharmacy, and Dentistry at the University of Bamako, Mali.

\section{Results}

\subsection{Frequency}

We have registered 33,784 obstetric admission including 28,376 dewberries with 9509 cases of cesarean 33.5\% (9509/28,376). The complication of maternal cesarean represented 3049 cases refers to $32.1 \%$ (3049/9509). 


\subsection{Sociodemographic Characteristic}

The epidemiologic and obstetric characteristics of the population are listed in Table 1.

\subsection{Risks Factors Complications of Cesarean}

They are listed in Table 2.

\subsection{Maternal Prognosis}

\subsubsection{Maternal Morbidity}

We have observed that bleeding was the most frequent intraoperative complication (8.3\%). The prevalence of bladder lesion was $1.1 \%$ and cardiorespiratory attack was $0.6 \%$. Maternal parameters strongly associated to the highest prevalence of intraoperative complications were: maternal age $>35$ years old $(\mathrm{ORa}=1.43)$, evacuation $(\mathrm{ORa}=3.07)$ absence of antenatal care $(\mathrm{ORa}=1.66)$ and premature rupture of membranes $(\mathrm{ORa}=2.04)$. The main complications have been: anemia and parietal infection respectively represented $52.51 \%$ and $18.89 \%$ and with 6 , $72 \%$ case of endometritis. The other types of complications were represented less than $5 \%$ of each case. The highest prevalence of postoperative complications were observed among teenager $(\mathrm{ORa}=1.49)$, evacuated $(\mathrm{ORa}=2.32)$, for patients who have developed pre-eclampsia/eclampsia $(\mathrm{ORa}=8.18)$ in case of praevia placenta $(\mathrm{ORa}=2.01)$, abruption placenta $(\mathrm{ORa}=2.38)$ and the absence of antenatal care $(\mathrm{ORa}=3.42)$.

\subsubsection{Maternal Mortality}

The death rate was multiplied by 2 for women referred in emergency compared to those who come by themselves. We noted a death rate diminution of $40 \%$ among primipares, when compared to multiparas with an $\mathrm{ORa}=0.61$ [IC 95\%: 0.40 - 0.93]. Women who went through cesarean operation before the term of the pregnancy had the highest death rate with an ORa = 1.57 [IC95\%: 1.10 2.25]. There is also an satastically significant association between pre eclampsia/eclampsia and the occurring of death among mothers who presented maternal complications of cesarean ORa $=2.34$ [IC 95\%; 1.49 - 3.68].

The death rate was multiplied by 10 for disease sicle cell mothers with the complications of cesarean operation $(\mathrm{P}<0.05)$.

\subsection{Fetal Prognosis}

\subsubsection{Perinatal Morbidity}

The prevalence of trauma, fetal anomalies, and low birth weight were respectively $0.7 \%, 1.8 \%$ and $4.5 \%$ in new born baby for caesarean mothers. The main observed trauma were broken clavicle (28 cases) elongation of brachial plexus ( 8 cases) and scalpel stroke (10 cases).

\subsubsection{Perinatal Mortality}

We have registered 1618 prenatal death with 1071 stillborn and 547 neonatal 
Table 1. The main sociodemographic characteristic:

\begin{tabular}{|c|c|c|}
\hline \multirow{2}{*}{ Variable } & \multicolumn{2}{|c|}{ Complications of caesarean } \\
\hline & $\begin{aligned} \text { Yes } & \\
\text { No }= & 3049(\%)\end{aligned}$ & $\begin{aligned} \text { No } & \\
\text { No }= & 6460(\%)\end{aligned}$ \\
\hline \multicolumn{3}{|l|}{ Years } \\
\hline$\leq 19$ & $775(25.4)$ & $980(15.2)$ \\
\hline $20-34$ & $1773(58.2)$ & $4366(67.6)$ \\
\hline$\geq 35$ & $501(16.4)$ & $114(17.2)$ \\
\hline \multicolumn{3}{|l|}{ Body Mass Index, $\mathrm{kg} / \mathrm{m}^{2}$} \\
\hline Normal & $2439(80.0)$ & $5393(83.6)$ \\
\hline Overweight & $525(17.2)$ & $1003(15.4)$ \\
\hline Obese & $85(2.8)$ & $64(1.0)$ \\
\hline \multicolumn{3}{|l|}{ Level of study } \\
\hline No schooling & $1962(64.3)$ & $1579(24.4)$ \\
\hline Primary & $249(8.2)$ & $1984(30.7)$ \\
\hline Secondary & $649(21.3)$ & $1599(24.8)$ \\
\hline Superior & $98(3.2)$ & $416(6.4)$ \\
\hline Unspecified & $91(3.0)$ & $882(13.7)$ \\
\hline \multicolumn{3}{|l|}{ Admission } \\
\hline Self admission & $1019(33.4)$ & $3572(55.2)$ \\
\hline Referred without emergency & $392(12.9)$ & $905(14.0)$ \\
\hline Referred Emergently & $1638(53.7)$ & $1983(30.8)$ \\
\hline \multicolumn{3}{|l|}{ Gestity } \\
\hline 1 & $1065(34.9)$ & $1669(25.9)$ \\
\hline $2-6$ & $1410(46.2)$ & $3739(57.9)$ \\
\hline$\geq 7$ & $574(18.8)$ & $1052(16.3)$ \\
\hline \multicolumn{3}{|l|}{ Parity } \\
\hline 1 & $1651(54.1)$ & $3247(50.2)$ \\
\hline $2-6$ & $1077(35.3)$ & $2667(41.4)$ \\
\hline$\geq 7$ & $321(10.5)$ & $546(8.5)$ \\
\hline \multicolumn{3}{|l|}{ Antenatale care } \\
\hline Yes & $2630(86.3)$ & $6140(95.0)$ \\
\hline No & $419(13.7)$ & $320(5.0)$ \\
\hline \multicolumn{3}{|l|}{ Context of caesarean } \\
\hline Emergency & $2880(94.5)$ & $5301(82.1)$ \\
\hline No emergency & $169(5.5)$ & $1159(17.9)$ \\
\hline
\end{tabular}

BMI normal: 18 - $25 \mathrm{~kg} / \mathrm{m}^{2}$; BMI overweight: $>25-30 \mathrm{~kg} / \mathrm{m}^{2}$; BMI obese $>30 \mathrm{~kg} / \mathrm{m}^{2}$. 
Table 2. The main risks factors complications of cesarean.

\begin{tabular}{|c|c|c|c|c|}
\hline Variables & OR crude (IC $95 \%)$ & P-value & $\mathrm{OR}_{\text {adjusted }}\left(\mathrm{IC}_{95 \%}\right)$ & P-value \\
\hline \multicolumn{5}{|l|}{ Years } \\
\hline $20-34$ & 1.00 & - & 1.00 & - \\
\hline$\leq 19$ & $1.97(1.77-2.20)$ & $<0.0001$ & $1.37(1.17-1.60)$ & $<0.0001$ \\
\hline \multicolumn{5}{|l|}{ Level of study } \\
\hline Schooling & 1.00 & - & 1.00 & - \\
\hline No Schooling & $5.01(4.55-5.51)$ & $<0.0001$ & $4.32(3.84-4.85)$ & $<0.0001$ \\
\hline \multicolumn{5}{|l|}{$\begin{array}{l}\text { Body mass index, } \\
\mathrm{kg} / \mathrm{m}^{2}\end{array}$} \\
\hline Normal & 1.00 & - & 1.00 & - \\
\hline Overweight & $1.17(1.04-1.31)$ & 0.009 & $2.03(1.73-2.37)$ & $<0.0001$ \\
\hline Obese & $2.94(2.12-4.08)$ & $<0.0001$ & $9.30(6.36-13.59)$ & $<0.0001$ \\
\hline \multicolumn{5}{|l|}{ Admission } \\
\hline Self admission & 1.00 & - & 1.00 & - \\
\hline Referred without & $1.52(1.32-1.74)$ & $<0.0001$ & $1.89(1.59-2.24)$ & $<0.0001$ \\
\hline Referred Emergently & $2.88(2.62-3.17)$ & $<0.0001$ & $2.39(2.11-2.70)$ & $<0.0001$ \\
\hline \multicolumn{5}{|l|}{ Parity } \\
\hline Multipara & 1.00 & - & 1.00 & - \\
\hline Primipara & $0.87(0.75-1.01)$ & 0.061 & $1.23(1.08-1.41)$ & 0.003 \\
\hline \multicolumn{5}{|l|}{ Duration of gestation } \\
\hline Terme & 1.00 & - & 1.00 & - \\
\hline Before terme & $1.44(1.29-1.60)$ & $<0.0001$ & $1.19(1.03-1.36)$ & 0.017 \\
\hline \multicolumn{5}{|l|}{ Antenatal care } \\
\hline Yes & 1.00 & - & 1.00 & - \\
\hline No & $3.05(2.62-3.55)$ & $<0.0001$ & $3.72(3.07-4.50)$ & $<0.0001$ \\
\hline \multicolumn{5}{|l|}{$\begin{array}{l}\text { Vulvovaginal infection } \\
\text { during pregnancy }\end{array}$} \\
\hline No & 1.00 & - & 1.00 & - \\
\hline Yes & $1.25(0.86-1.83)$ & 0.246 & $1.53(0.95-2.44)$ & 0.078 \\
\hline \multicolumn{5}{|l|}{ Pre-eclampsia/eclampsia } \\
\hline \multicolumn{5}{|l|}{ No } \\
\hline Yes & $10.24(8.22-12.75)$ & $<0.0001$ & $8.50(6.60-10.95)$ & $<0.0001$ \\
\hline \multicolumn{5}{|l|}{ Fever labor } \\
\hline No & 1.00 & - & 1.00 & - \\
\hline Yes & $2.39(1.81-3.16)$ & $<0.0001$ & $1.75(1.22-2.52)$ & 0.003 \\
\hline \multicolumn{5}{|l|}{$\begin{array}{l}\text { Premature rupture of } \\
\text { membrane }\end{array}$} \\
\hline No & 1.00 & - & 1.00 & - \\
\hline Yes & $1.29(0.93-1.79)$ & 0.134 & $1.18(0.78-1.79)$ & 0.427 \\
\hline
\end{tabular}




\section{Continued}

\begin{tabular}{ccccc}
\hline $\begin{array}{c}\text { Praevia placenta } \\
\text { No } \\
\text { Yes }\end{array}$ & $1.79(1.41-2.26)$ & $<0.0001$ & $2.11(1.57-2.82)$ & $<0.0001$ \\
$\begin{array}{c}\text { Prolonged labor } \\
\text { No }\end{array}$ & 1.00 & - & 1.00 & - \\
Yes & $1.41(1.13-1.77)$ & 0.003 & $1.63(1.23-2.17)$ & 0.001 \\
Context of caesarean & & & & \\
No emergency & 1.00 & - & 1.00 & - \\
Emergency & $1.10(1.01-1.20)$ & 0.032 & $2.07(0.70-6.15)$ & 0.191 \\
Length of cesarean & & & & \\
$<60$ mn & 1.00 & - & 1.00 & - \\
$>60$ mn & $13.68(11.61-16.14)$ & $<0.0001$ & $16.40(13.63-19.74)$ & $<0.0001$ \\
\hline
\end{tabular}

death. The highest death rate has been observed in cold and emergency referred patients compared to patients who came by themselves; ORa were respectively 1.71 [IC 95\%: 1.35 - 2.26] and 2.25 [IC 95\%; $1.88-2.69$ ].

The death rate was respectively multiplied by 2.33 and 1.46 for new born babies from mothers who gave birth before term and who didn't realize antenatal care. Light amniotic liquid 8.33 [IC 95\%: 6.90 - 10.05]; the meconial liquid ORa: 28.01 [IC 95\%: 19.51 - 40.20], aspect liquid amniotic pea puree ORa: 4.87 [IC 95\%: 3.07 - 7.72]; yellowish and hematic liquid amniotic ORa: 33.41 [IC 95\%: 25.53 - 43.72] were strongly associated with perinatal death rate.

\section{Discussion}

The limitations in our study: we report here an analysis of the complication cesarean delivery during 11 years period in a teaching hospital in Mali (West Africa). This obstetric database hospital it is not the results of the global population in Mali.

The current situation complications of cesarean delivery rates in developing countries is very complex with large differences between countries, within countries, and between health centers in Table 3 .

In sub-Saharan Africa cesarean is very often realized in emergency even extreme one [22] [23] [24]. According to several authors, the high frequency of complications is linked to the insufficiency of competent human resources and material resources [16] [17] [20] [24].

In fact, south Africa of the Sahara has only $1 \%$, qualified human resources in the world in the context where our region supports $25 \%$ the burden of the disease [25] [26]. This insufficiency, associated with the poor organization coverage of the referral system, explains a significant part of the complications associated with cesarean section affect $1 / 5$ to $1 / 3$ parturient women who have given birth by caesarean. 
Table 3. Complications of cesarean in African countries.

\begin{tabular}{|c|c|c|c|c|c|}
\hline Authors & Countries & Years & $\begin{array}{l}\text { Complications } \\
\text { of cesarean }\end{array}$ & Effective & Study \\
\hline Benkirane S. et al. [19] & Maroc & 2017 & $19.45 \%$ & 2416 & $\begin{array}{l}\text { Descriptive and } \\
\text { retrospective }\end{array}$ \\
\hline $\begin{array}{l}\text { Kinenkinda X. et al. } \\
{[20]}\end{array}$ & $\mathrm{RDC}$ & 2017 & $11.6 \%$ & 3643 & $\begin{array}{l}\text { Descriptive analytical } \\
\text { and retrospective }\end{array}$ \\
\hline Ouattara A. et al. [21] & $\begin{array}{l}\text { Burkina } \\
\text { Faso }\end{array}$ & 2015 & $18.8 \%$ & 5027 & Cross sectional \\
\hline Ngowa J.D.K. et al. [16] & Cameroun & 2012 & $16.95 \%$ & 460 & Cohort \\
\hline Siby O. et al. [17] & Mali & 2009 & $31.3 \%$ & 1081 & Prospective \\
\hline Our study & Mali & $2003-2013$ & $32.1 \%$ & 3049 & $\begin{array}{l}\text { Cross sectional } \\
\text { analytic }\end{array}$ \\
\hline
\end{tabular}

That poor organization of the referral during emergency explains that this modality is the factor which is associated with the occuring of post-cesarean complications overall, but also with each of the complications taken individually in our work. The means of transport used were often unsuitable, no medical with precarious hygiene conditions [27] [28]. A strong statistically significant association between abruption placenta and the prevalence of post-operative complications such as hemorrhage, anemia and parietal infections was found. Abruption placenta can cause a high blood loss requiring a blood transfusion [29] [30]. These extreme emergencies do not accommodate the delay in treatment and the insufficient unavailability of blood products in our contexts [30]. Otherwse, abruption placenta was among the main factors influencing the perinatal death in our study. This explained by the anoxia at causes and aggravated by the delay in treatment in case of the emergency [31] [32]. In our study, the risk of intrapartum asphyxia was multiplied by 3.7 in mothers who have an abruption placenta [33]. In some developing countries, the perinatal mortality in case of abruption placenta can reach or exceed $60 \%$ [26], whereas in the developed countries it's about $9 \%$ and $12 \%$ [34] [35]. Mortality associated with abruption placenta is 25 times higher [34] [36]. Our stillborn rate is $11.3 \%$ among all cesarean mothers. This rate is in the interval of stillborn rates associated with cesarean section [37] [38].

In our work, the mode of admission in emergency or without emergency was among the main factors influencing perinatal death. The criteria of morbidity are very difficult to determine according to Racine et al., because several aspects are taking into account [39] and it's the reflect of fetus previous pain rather than it's due to cesarean operation [40]. If cesarean is only performed for medical reason, the neonatal result is excellent [41] [42]. More than $50 \%$ of deaths occurred during the night between 8:00 p.m. and 8:00 a.m. [43]. The nursing quality, the residents experience used for guards and their insufficient supervisions as well the health workers tireness as risk factors of perinatal death were demonstrated [43] [44]. 
In 2015, 25\% of emergency cesarean operation was performed in Mali at least in 64 minutes after making decision [45].

Several studies report that deaths are often due to delayed care [46] [47]. Insufficient of poor quality of intra-partum care on new born future was reported in an African maternity by Maaloe et al. [48].

\section{Conclusion}

Complications of cesarean rate were high in our study. The improvement of quality of prenatal care, the reorganization and revitalization of reference and non-reference system will help to program cesarean and reduce morbidity related to cesarean operation.

\section{Conflicts of Interest}

The authors declare no conflicts of interest regarding the publication of this paper.

\section{References}

[1] Betran, A.P., Ye, J., Moller, A.B., et al. (2016) The Increasing Trend in Caesarean Section Rates: Global, Regional and National Estimates: 1990-2014. PLoS ONE, 11, e0148343. https://doi.org/10.1371/journal.pone.0148343

[2] Gibbons, L., Belizan, J., Lauer, J.A., et al. (2010) The Global Numbers and Costs of Additionally Needed and Unnecessary Caesarean Sections Performed per Year: Overuse as a Barrier to Universal Coverage. World Health Report No. 30.

[3] Teguete, I., Traore, Y., Sissoko, A., et al. (2012) Determining Factors of Cesarean Delivery Trends in Developing Countries: Lessons from Point G National Hospital (Bamako-Mali). In: Salim, R., Ed., Cesarean Delivery, InTech, London, 161-200. http://www.intechopen.com/books/cesarean-delivery/determining-factors-of-cesare an-delivery-trends-in-developing-countries-lessons-from-point-g-nat https://doi.org/10.5772/47914

[4] Ngowa, J.D.K. (2015) Complications maternelles précoces de la césarienne: À propos de 460 cas dans deux hôpitaux universitaires de Yaoundé, Cameroun. Pan African Medical Journal, 21, 1. https://doi.org/10.11604/pamj.2015.21.265.6967

[5] Gibbons, L., Belizan, J.M., Lauer, J.A., et al. (2012) Inequities in the Use of Cesarean Section Deliveries in the World. American Journal of Obstetrics \& Gynecology, 206, 331.e1-19. https://doi.org/10.1016/j.ajog.2012.02.026

[6] Hannah, M.E., Hannah, W.J., Hewson, S.A., et al. (2000) Planned Caesarean Section versus Planned Vaginal Birth for Breech Presentation at Term: A Randomised Multicentre Trial. The Lancet, 356, 1375-1383. https://doi.org/10.1016/S0140-6736(00)02840-3

[7] World Health Organization (WHO) (2015) Caesarean Sections Should Only Be Performed When Medically Necessary in 10 April 2015. Geneva. https://www.who.int/mediacentre/news/releases/2015/caesarean-sections/en/

[8] Hannah, M.E., Whyte, H., Hannah, W.J., et al. (2004) Maternal Outcomes at 2 Years after Planned Cesarean Section versus Planned Vaginal Birth for Breech Presentation at Term: The International Randomized Term Breech Trial. American Journal of Obstetrics \& Gynecology, 191, 917-927. 
https://doi.org/10.1016/j.ajog.2004.08.004

[9] Chauvin, C., Raynal, P., Soltane, S., et al. (2009) Fetal Injuries during Cesarean: Frequency, Risk Factors and Prevention. Gynécologie Obstétrique \& Fertilité, 37, 321-324. https://doi.org/10.1016/j.gyobfe.2009.01.009

[10] Robson, M., Hartigan, L. and Murphy, M. (2013) Methods of Achieving and Maintaining an Appropriate Caesarean Section Rate. Best Practice \& Research: Clinical Obstetrics \& Gynaecology, 27, 297-308. https://doi.org/10.1016/j.bpobgyn.2012.09.004

[11] Lumbiganon, P., Laopaiboon, M., Gulmezoglu, A.M., et al. (2010) Method of Delivery and Pregnancy Outcomes in Asia: The WHO Global Survey on Maternal and Perinatal Health 2007-08. The Lancet, 375, 490-499. https://doi.org/10.1016/S0140-6736(09)61870-5

[12] Villar, J., Carroli, G., Zavaleta, N., et al. (2007) Maternal and Neonatal Individual Risks and Benefits Associated with Caesarean Delivery: Multicentre Prospective Study. BMJ, 335, 1025. https://doi.org/10.1136/bmj.39363.706956.55

[13] Mariko, S.L. (2008) Les complications maternelles de la césarienne au centre de santé de reference de koutiala. Thèse de médecine Bamako, No. 546.

[14] van Ham, M.A., van Dongen, P.W. and Mulder, J. (1997) Maternal Consequences of Caesarean Section. A Retrospective Study of Intra-Operative and Postoperative Maternal Complications of Caesarean Section during a 10-Year Period. European Journal of Obstetrics \& Gynecology and Reproductive Biology, 74, 1-6. https://doi.org/10.1016/S0301-2115(97)02725-5

[15] Renate, M.I., Häger, E., Daltveit, K.A., et al. (2004) Complication of Cesarean Delivery: Rates and Risk Factors. American Journal of Obstetrics \& Gynecology, 190, 428-434. https://doi.org/10.1016/j.ajog.2003.08.037

[16] Jennifer, L. (2006) The MFMU Cesarean Registry: Impact of Time of Day on Cesarean Complications. American Journal of Obstetrics and Gynecology, 195, 1132-1137. https://doi.org/10.1016/j.ajog.2006.06.009

[17] Siby, O. (2009) Etude des suites de couches post césariennes dans le service de gynécologie et d'obstétrique du CHU Gabriel Touré. Thèse de médecine Bamako, No. 537.

[18] Koné, A.D. (2005) Facteurs de risque des complications maternelles post-césariennes à l'hôpital gabriel touré et à l'hôpital du point G. Thèse de médecine Bamako, No. 224.

[19] Benkirane, S., Saadi, H. and Mimouni, A. (2017) Epidemiological Profile of Maternal Complications Related to Cesarean Section at the Al Farabi Hospital in Oujda. The Pan African Medical Journal, 27, 108. https://doi.org/10.11604/pamj.2017.27.108.10036

[20] Kinenkinda, X., Mukuku, O., Chenge, F., et al. (2017) Césarienne à Lubumbashi, république démocratique du Congo I: Fréquence, indications et mortalité maternelle et périnatale. The Pan African Medical Journal, 27, 72. https://doi.org/10.11604/pamj.2017.27.72.12147

[21] Ouattara, A., Yameogo, R.B., Kabore, F.X.G., Kiemtore, S., Kain, D.P., Sawadogo, Y.A., Dao, Y., Ouedraogo, I., Ouedraogo, C.M., Ouedraogo, A., Millogo, T.F. and Thieba, B.B. (2017) Prognosis of Misgav-Ladach Caesarean Sections in an African Environment: Case of the Banfora Regional Hospital in Burkina Faso about 110 Cases. Open Journal of Obstetrics and Gynecology, 7, 1006-1015. https://doi.org/10.4236/ojog.2017.79101

[22] Diallo, F.B., Bangoura, S. and Camara, Y. (1998) Césarienne: Facteur de réduction de 
la morbidité et de la mortalité foeto-maternelle. Médecine d Afrique Noire, 45, 359-364.

[23] Pete, Y., Ouattara, A., Koffi, N., et al. (2012) Césariennes en urgence: Pronostic materno-fotal au CHU de Cocody d'Abidjan. African Journal of Emergency Medicine, 17, N1.

[24] Biccard, B.M., Madiba, T.E., Kluyts, H.L., et al. (2018) Perioperative Patient Outcomes in the African Surgical Outcomes Study: A 7-Day Prospective Observational Cohort Study. The Lancet, 391, 1589-1598. https://doi.org/10.1016/S0140-6736(18)30001-1

[25] WHO (2006) Working Together for Health. The World Health Report. http://apps.who.int/iris/bitstream/handle/10665/43432/9241563176 eng.pdf?sequen $\underline{\mathrm{ce}}=1$

[26] Ozumba, B.C. and Nwogu-Ikojo, E.E. (2008) Avoidable Maternal Mortality in Enugu, Nigeria. Public Health, 122, 354-360. https://doi.org/10.1016/j.puhe.2007.04.018

[27] Hussein, J., Hirose, A., Owolabi, O., et al. (2016) Maternal Death and Obstetric Care Audits in Nigeria: A Systematic Review of Barriers and Enabling Factors in the Provision of Emergency Care. Reproductive Health, 13, 47. https://doi.org/10.1186/s12978-016-0158-4

[28] Nyengidiki, T. and Allagoa, D.O. (2011) Rupture of the Gravid Uterus in a Tertiary Health Facility in the Niger Deltaregion of Nigeria: A 5-Year Review. Nigerian Medical Journal, 52, 230-234. https://doi.org/10.4103/0300-1652.93794

[29] Tikkanen, M., Gissler, M., Metsaranta, M., et al. (2009) Maternal Deaths in Finland: Focus on Placental Abruption. Acta Obstetricia et Gynecologica Scandinavica, 88, 1124-1127. https://doi.org/10.1080/00016340903214940

[30] Gabbay-Benziv, R., Ashwal, E., Lahav-Ezra, H., et al. (2014) Decision-to-Delivery Interval in Suspected Placental Abruption-Association with Pregnancy Outcome. The Journal of Maternal-Fetal \& Neonatal Medicine, 27, 1680-1683. https://doi.org/10.3109/14767058.2013.871703

[31] Allred, L.S. and Batton, D. (2004) The Effect of Placental Abruption on the Short-Term Outcome of Premature Infants. The American Journal of Perinatology, 21, 157-162. https://doi.org/10.1055/s-2004-823770

[32] Matsuda, Y., Maeda, T. and Kouno, S. (2003) Comparison of Neonatal Outcome Including Cerebral Palsy between Abruptio Placentae and Placenta Previa. European Journal of Obstetrics \& Gynecology and Reproductive Biology, 106, 125-129. https://doi.org/10.1016/S0301-2115(02)00219-1

[33] Heinonen, S. and Saarikoski, S. (2001) Reproductive Risk Factors of Fetal Asphyxia at Delivery: A Population Based Analysis. Journal of Clinical Epidemiology, 54, 407-410. https://doi.org/10.1016/S0895-4356(00)00329-2

[34] Ananth, C.V. and Wilcox, A.J. (2001) Placental Abruption and Perinatal Mortality in the United States. American Journal of Epidemiology, 153, 332-337. https://doi.org/10.1093/aje/153.4.332

[35] Kyrklund-Blomberg, N.B., Gennser, G. and Cnattingius, S. (2001) Placental Abruption and Perinatal Death. Paediatric and Perinatal Epidemiology, 15, 290-297. https://doi.org/10.1046/j.1365-3016.2001.00352.x

[36] Konje, J.C. and Taylor, D.J. (2006) Bleeding in Late Pregnancy. 3rd Edition, WB Saunders Co., Edinburgh, 1259-1275.

[37] Mongbo, V., Ouendo, E.M., Agueh, V., et al. (2016) Factors Associated with PostCesarean Stillbirth in 12 Hospitals in Benin: A Cross-Sectional. The Pan African 
Medical Journal, 25, 117. https://doi.org/10.11604/pamj.2016.25.117.9827

[38] McClure, E.M., Pasha, O., Goudar, S.S., et al. (2011) Epidemiology of Stillbirth in Low-Middle Income Countries: A Global Network Study. Acta Obstetricia et Gynecologica Scandinavica, 90, 1379-1385. https://doi.org/10.1111/j.1600-0412.2011.01275.x

[39] Racinet, C. and Favier, M. (1984) La césarienne: Indications, Techniques, Complications. Paris, 186 p.

[40] Palot, M. (2000) Césarienne: technique d'anesthésie et soin post-opératoire. Journal de Gynécologie Obstétrique et Biologie de la Reproduction, 29, 96-107.

[41] Word Health Organization (WHO) (2004) Maternal Mortality in 2000: Estimates Developed by WHO, UNICEF, and UNFPA. Vol. 85, WHO, Geneva, 460-471.

[42] Picaud, A., Nlome-Nze, A.R., Kouvahe, V., et al. (1990) Les indications de césarienne et leur évolution au centre hospitalier de Libreville. Revue Française de Gynécologie et d'obstétrique, 85, 393-398.

[43] Gould, J.B., Qin, C. and Chavez, G. (2005) Time of Birth and the Risk of Neonatal Death. Obstetrics \& Gynecology, 106, 352-358. https://doi.org/10.1097/01.AOG.0000168627.33566.3c

[44] Lee, K.A. and Lipscomb, J. (2003) Sleep among Shiftworkers-A Priority for Clinical Practice and Research in Occupational Health Nursing. AAOHN Journal, 51, 418-420. https://doi.org/10.1177/216507990305101003

[45] Traoré, P.B. (2017) La césarienne dans les structures sanitaires au Mali: Fréquence, indication, pronostic. Thèse Médecine, Bamako, No. 14.

[46] Issah, K., Nang-Beifubah, A. and Opoku, C.F. (2011) Maternal and Neonatal Survival and Mortality in the Upper West Region of Ghana. International Journal of Gynecology \& Obstetrics, 113, 208-210. https://doi.org/10.1016/j.ijgo.2011.01.007

[47] Bloom, S.L., Leveno, K.J., Spong, C.Y., et al. (2006) Decision-to-Incision Times and Maternal and Infant Outcomes. Obstetrics \& Gynecology, 108, 6-11. https://doi.org/10.1097/01.AOG.0000224693.07785.14

[48] Maaløe, N., Housseine, N., Bygbjerg, I.C., et al. (2016) Stillbirths and Quality of Care during Labour at the Low Resource Referral Hospital of Zanzibar: A CaseControl Study. BMC Pregnancy Childbirth, 16, 351. https://doi.org/10.1186/s12884-016-1142-2 